\title{
Sulforaphane suppresses oral cancer cell migration by regulating cathepsin $\mathbf{S}$ expression
}

\author{
Chang-Tai Chen ${ }^{1,2, *}$, Ming-Ju Hsieh ${ }^{3,4,5, *}$, Yi-Hsien Hsieh ${ }^{6}$, Min-Chieh Hsin ${ }^{3}$, Yi-Ting \\ Chuang $^{3}$, Shun-Fa Yang ${ }^{3,7}$, Jia-Sin Yang ${ }^{3,7}$ and Chiao-Wen Lin ${ }^{1,2,8}$ \\ ${ }^{1}$ Institute of Oral Sciences, Chung Shan Medical University, Taichung, Taiwan \\ ${ }^{2}$ School of Dentistry, Chung Shan Medical University, Taichung, Taiwan \\ ${ }^{3}$ Institute of Medicine, Chung Shan Medical University, Taichung, Taiwan \\ ${ }^{4}$ Cancer Research Center, Changhua Christian Hospital, Changhua, Taiwan \\ ${ }^{5}$ Graduate Institute of Biomedical Sciences, China Medical University, Taichung, Taiwan \\ ${ }^{6}$ Institute of Biochemistry, Microbiology and Immunology, Chung Shan Medical University, Taichung, Taiwan \\ ${ }^{7}$ Department of Medical Research, Chung Shan Medical University Hospital, Taichung, Taiwan \\ ${ }^{8}$ Department of Dentistry, Chung Shan Medical University Hospital, Taichung, Taiwan \\ *These authors contributed equally to this work \\ Correspondence to: Chiao-Wen Lin, email: cwlin@csmu.edu.tw \\ Jia-Sin Yang, email: cshe857@csh.org.tw
}

Keywords: sulforaphane; cathepsin S; LC3; oral cancer; migration

Received: November 09, $2017 \quad$ Accepted: February 28, $2018 \quad$ Published: April 03, 2018

Copyright: Chen et al. This is an open-access article distributed under the terms of the Creative Commons Attribution License 3.0 (CC BY 3.0), which permits unrestricted use, distribution, and reproduction in any medium, provided the original author and source are credited.

\section{ABSTRACT}

Sulforaphane has been demonstrated to exert numerous biological effects, such as neuroprotective, anti-inflammatory, and anticancer effects. However, the detailed effects of sulforaphane on human oral cancer cell migration and the underlying mechanisms remain unclear. In this study, we observed that sulforaphane attenuated SCC-9 and SCC-14 cell motility and invasiveness by reducing cathepsin S expression. Moreover, sulforaphane increased microtubule-associated protein 1 light chain 3 (LC3) conversion, and the knockdown of LC3 by siRNA increased cell migration ability. Regarding the mechanism, sulforaphane inhibited the cell motility of oral cancer cells through the extracellular signal-regulated kinase (ERK) pathway, which in turn reversed cell motility. In conclusion, sulforaphane suppress cathepsin $\mathbf{S}$ expression by inducing autophage through ERK signaling pathway. Thus, cathepsin S and LC3 may be new targets for oral cancer treatment.

\section{INTRODUCTION}

Oral cancer is a common neoplasm, and its incidence rate ranks fourth among cancer in males in Taiwan. Numerous intensive studies have focused on cancer pathogenesis at the molecular level, providing new therapy options [1]. Multiple pathways are involved in tumor progression, including dysfunction of cell adhesion and degradation of extracellular matrix (ECM) components [2,3]. It is widely accepted that proteinase degrades the ECM and facilitates malignant progression. Cathepsin $\mathrm{S}$ is a member of the lysosomal cysteine family that can degrade ECM elements such as laminin, fibronectin, elastin, and certain collagens [4]. Cathepsin S was reported to play numerous roles in distinct tumorigenic processes, including angiogenesis, metastasis, and apoptosis [5-9]. Moreover, Tsai et al. reported that cathepsin $\mathrm{S}$ inhibitors could be useful in prevent or delay cancer metastasis [10]. Reports have revealed that inhibition of cathepsin S induces autophagy in various types of human cancer $[11,12]$. Autophagy is an evolutionarily conserved catabolic process that maintains cellular and energetic homeostasis by providing nutrients and mitigating cellular damage [13]. Autophagy plays a 
key role in regulating the balance between cell survival and cell death. Autophagy modulation was suggested to be beneficial for cancer prevention and therapy [14].

Sulforaphane is a natural phytochemical compound derived from cruciferous plants, such as broccoli, cabbage, and cauliflower [15]. Sulforaphane has been demonstrated to exert numerous biological effects, such as neuroprotective, anti-inflammatory, anti-angiogenesis and anticancer effects [16-18]. Studies have reported that sulforaphane eliminates cancer stem cells in various cancers $[19,20]$. Several mechanisms have been suggested to clarify these effects, including cell apoptosis [21], angiogenesis [22], and the modulation of cytochrome P-450 enzymes [23]. Myzak et al. demonstrated that sulforaphane acts as a histone deacetylase inhibitor in human colon cancer cells by regulating the promoter region of the $\mathrm{p} 21$ and BAX genes [24]. In addition, administering sulforaphane to prostate cancer cells induced G2/M cell cycle arrest [25] and reactive oxygen species (ROS) generation [26]. Alongside its chemopreventive properties, sulforaphane was demonstrated to have antimicrobial activity against Helicobacter pylori, a strong risk factor for gastric cancer [27]. Moreover, evidence exists regarding the anticancer effect of sulforaphane on other cancer cells, but few studies have examined this effect in oral cancer. Therefore, the mechanism underlying the effects of sulforaphane in oral cancer is worth investigating.

\section{RESULTS}

\section{Effects of sulforaphane on migration and invasion in vitro in SCC-9 and SCC-14 cells}

To investigate the effects of sulforaphane treatment on the viability of SCC-9 and SCC-14 oral cancer cells, an MTT assay was performed. Sulforaphane was administered to SCC-9 and SCC-14 cells for $24 \mathrm{~h}$ and $48 \mathrm{~h}$ at various concentrations $(0,2.5,5$ and $10 \mu \mathrm{M})$, as shown in Figure 1A and $1 \mathrm{~B}$. The data revealed that high-dose sulforaphane only reduced cell viability by $18 \%$ in SCC-9 cells after $48 \mathrm{~h}$ treatment. We further detected the migratory ability of SCC9 and SCC-14 cells after sulforaphane treatment using a wound healing assay. Figure 1C and 1D show representative photographs of sulforaphane-reduced migration of SCC-9 and SCC- 14 cells at $24 \mathrm{~h}$ and $48 \mathrm{~h}$, respectively. To further investigate the effects of sulforaphane on cell migration and invasion, cells of both types were treated with or without sulforaphane for $24 \mathrm{~h}$ and $48 \mathrm{~h}$, and samples were seeded in the upper chambers of an uncoated or Matrigelcoated filter. The same results were obtained; the numbers of both migratory and invasive cells were reduced when SCC-9 and SCC-14 cells were treated with sulforaphane (Figure 2A-2D).

\section{Cathepsin S expression was downregulated after treatment with sulforaphane}

Because the dysregulation of proteinase expression is common in cancer progression, we used a human proteinase array kit to analyze the proteinase profile. As shown in Figure $3 \mathrm{~A}$, the protein expression of cathepsin $\mathrm{S}$ was lower in SCC-9 cells treated with sulforaphane at $10 \mu \mathrm{M}$ than in the control group. In addition, we used Western blotting to confirm the cathepsin S protein expression; the data indicated that cathepsin $\mathrm{S}$ expression was reduced in both SCC-9 and SCC-14 cells (Figure 3B). Cathepsin S plays was demonstrated to play a vital role in numerous malignancies [7]. To repress cathepsin S activity, cathepsin $\mathrm{S}$ siRNA and an inhibitor of cathepsin S, Z-FL-COCHO (ZFL), were used in the subsequent experiments. The transfection and expression of cathepsin S-specific siRNA and the cathepsin $\mathrm{S}$ inhibitor significantly reduced cathepsin S protein expression in SCC-9 and SCC-14 cells (Figure 3C and $3 \mathrm{E})$. Figure $3 \mathrm{D}$ and $3 \mathrm{~F}$ both depict downregulated cathepsin $\mathrm{S}$ expression inhibiting the migration ability of SCC-9 and SCC-14 cells. These results indicate that sulforaphane treatment represses SCC-9 and SCC-14 cell migration by regulating cathepsin $\mathrm{S}$ expression.

\section{Effects of sulforaphane-induced autophagy and LC3 expression}

Relevant literature indicates that targeting cathepsin $\mathrm{S}$ induces tumor cell autophagy and increases microtubuleassociated protein 1 light chain 3 (LC3) protein expression $[12,28]$. During autophagy, the cytoplasmic form (LC3-I) is cleaved and lipidated to form LC3-II. To investigate whether autophagy plays a role in sulforaphane treatment of SCC-9 and SCC-14 cells, LC3 expression was examined. As shown in Figure 4A and 4B, LC3-II expression was elevated after sulforaphane treatment in SCC-9 and SCC14 cells. Microscopy-based green fluorescent protein (GFP)-LC3 puncta formation assays were performed to confirm the aforementioned observation. The higher the concentration of sulforaphane treatment was, the greater the density of GFP-LC3 puncta in SCC-9 and SCC-14 cells (Figure 4C). To determine the relationship between LC3 expression and migration ability, we transfected SCC-9 and SCC-14 cells with LC3 siRNA. Knockdown of LC3 by siRNA increased the migration ability in both cell lines (Figure 5A and 5B). To explore whether cathepsin $\mathrm{S}$ regulates LC3 expression, cathepsin S siRNA and ZFL were used. As shown in Figure 5C and 5D, treatment of cells with cathepsin S siRNA and ZFL increased LC3-II expression in both SCC-9 and SCC-14 cells. Taken together, these results suggest that sulforaphane upregulates LC3-II expression by regulating cathepsin $\mathrm{S}$ expression, which results in the inhibition of cell migration. 


\section{Sulforaphane alters levels of proteins associated with migration}

To investigate the molecular mechanism of cathepsin $\mathrm{S}$ inhibition by sulforaphane, we examined the mTOR/AKT and MAPK signaling pathways, which are implicated in autophagy. The data showed that sulforaphane treatment did not affect AKT/mTOR or beclin 1 pathway expression (Figure 6A). However, sulforaphane obviously elevated the phosphorylation of ERK1/2. In addition, combined treatment with
U0126, a MEK inhibitor, and sulforaphane reversed the inhibition of LC3-II conversion and migration by treatment with sulforaphane alone (Figure 6B and $6 \mathrm{C}$ ). Moreover, combined treatment with ERK siRNA and sulforaphane also reversed the inhibition of cell migration by treatment with sulforaphane alone (Figure 6D).Taken together, these results suggest that sulforaphane represses cathepsin $\mathrm{S}$ by upregulating LC3-II expression; however, this occurs independently of mTOR/AKT-induced autophagy, at least mediating MAPK signaling pathways.
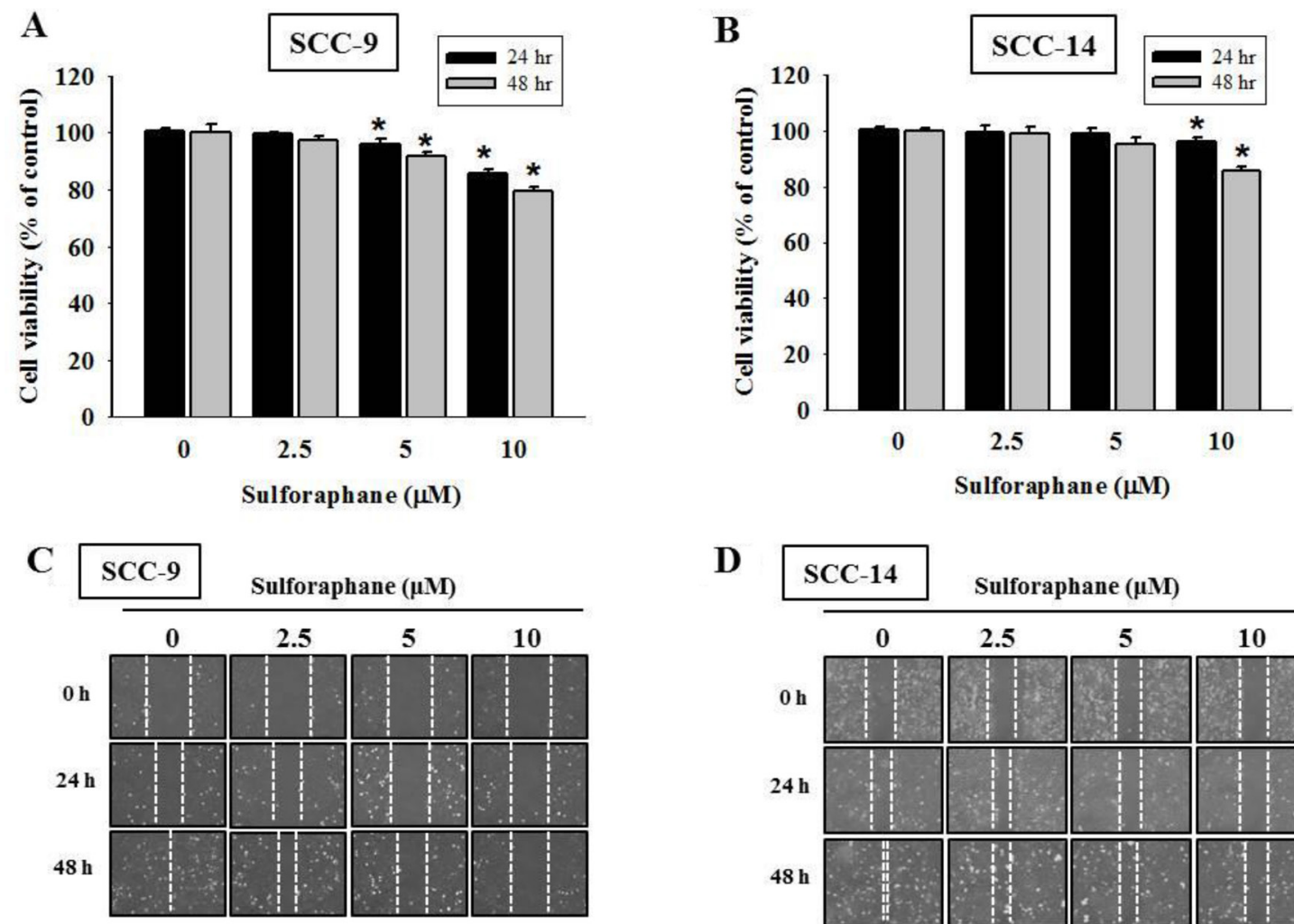

D
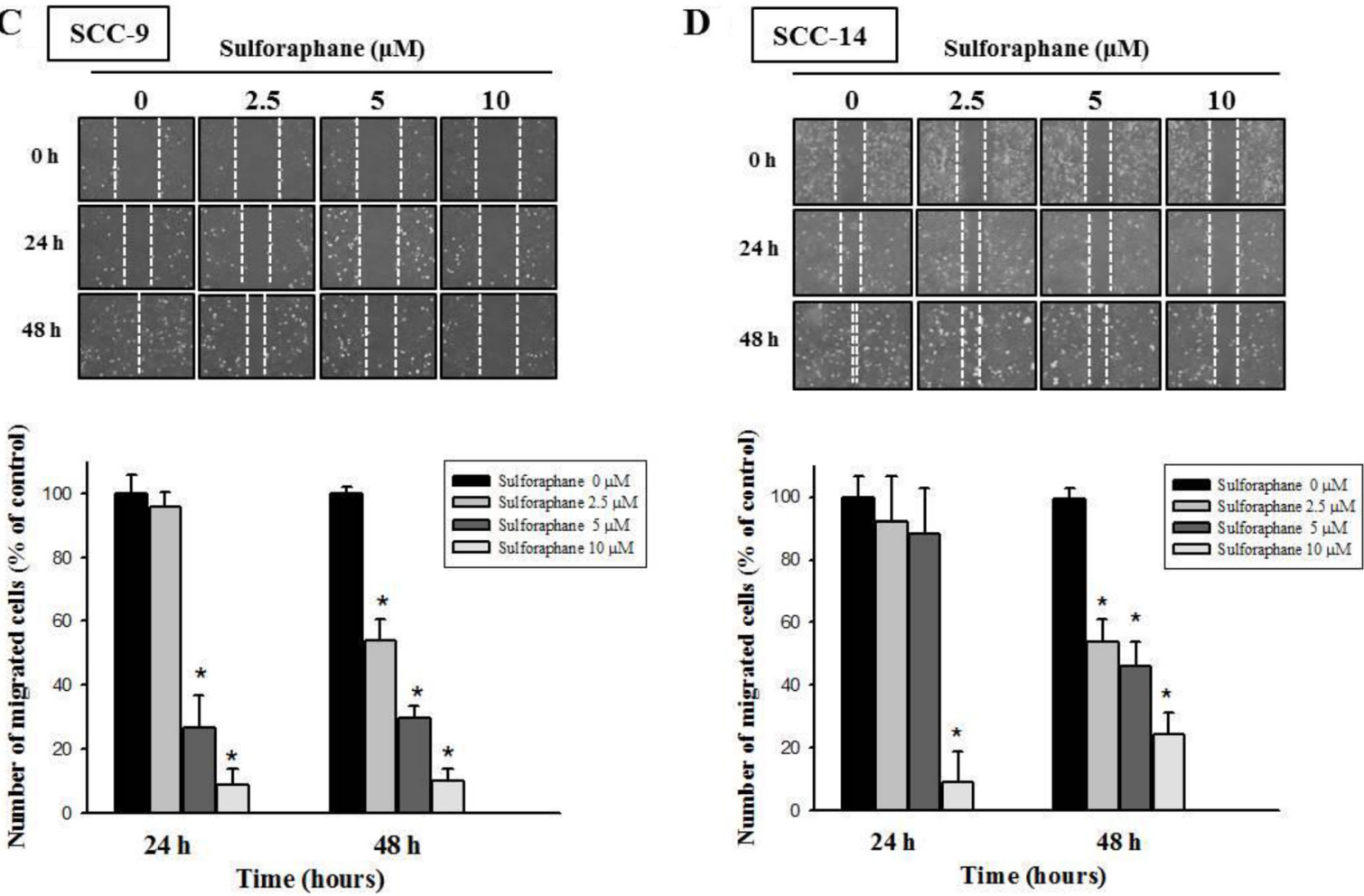

Figure 1: Effect of sulforaphane on cell viability and cell motility of SCC-9 and SCC-14 cells. SCC-9 (A) and SCC-14 (B) cells were treated with different concentrations $(0,2.5,5$ and $10 \mu \mathrm{M})$ of sulforaphane for $24 \mathrm{~h}$ and $48 \mathrm{~h}$ before being subjected to an MTT assay for cell viability. The values represented the means $\pm \mathrm{SD}$ of at least three independent experiments. ${ }^{*} p<0.05$, compared with the vehicle group. The motility of SCC-9 (C) and SCC-14 (D) cells were assessed by in vitro wound closure assay with different concentration of sulforaphane $(0,2.5,5$ and $10 \mu \mathrm{M})$ at different time points. A quantitative assessment of cell number in the denuded zone is the mean $\pm \mathrm{SD}(n=3) .{ }^{*} p<0.05$, compared with the vehicle group. 


\section{DISCUSSION}

Natural dietary agents comprise various types of biologically active compounds, including polyphenols, alkaloids, and isothiocyanates, that may provide abundant health benefits beyond basic nutrition. Research over the last decade has shown that dietary components in vegetables and fruits repress cancer growth [29]. Sulforaphane, a member of the isothiocyanate family, is abundant in widely consumed cruciferous vegetables and

\section{A $\mathrm{SCC}-9$}

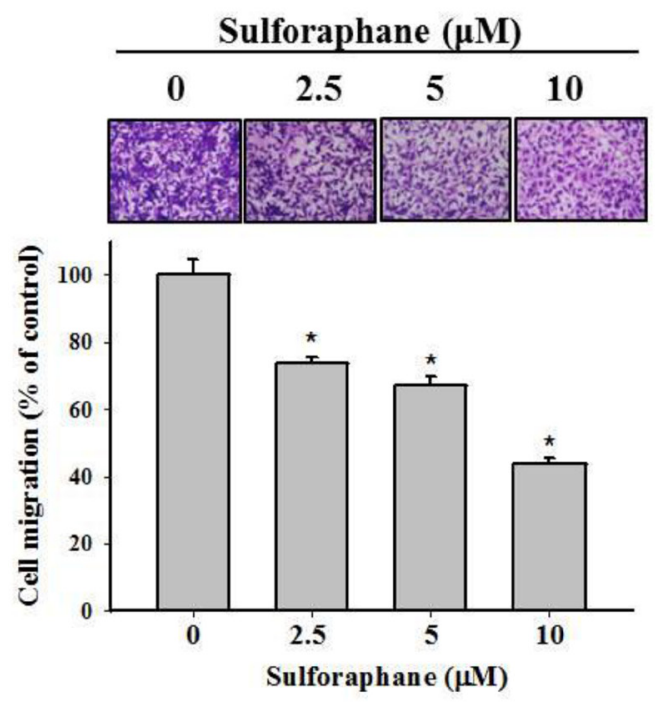

C $\mathrm{SCC}-9$

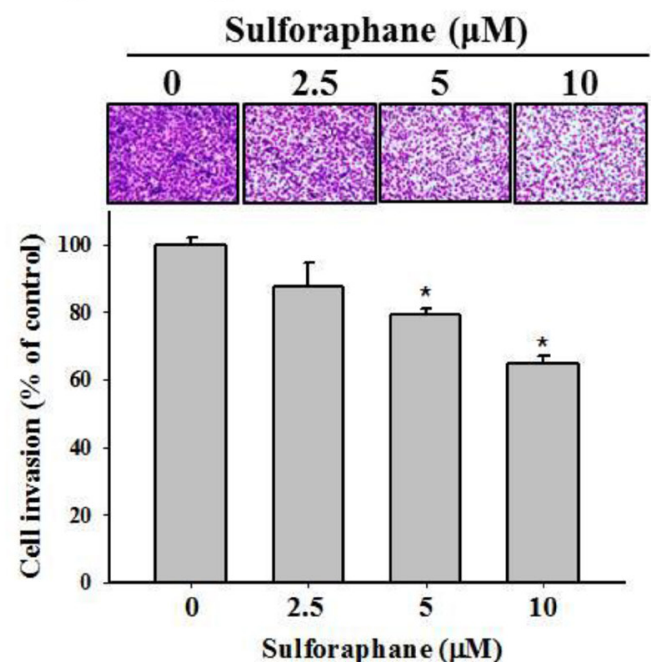

has potential anticarcinogenic properties. Early research focused on the inhibition activity of enzymes involved in carcinogen activation by sulforaphane [30]. However, more recent studies have demonstrated that sulforaphane offers protection against cancer development, through mechanisms including apoptosis induction, cancer stem cell proliferation, and autophagy modulation. In the present study, we demonstrated that sulforaphane inhibits cell migration by regulating cathepsin $\mathrm{S}$ and expression of its downstream target LC3.
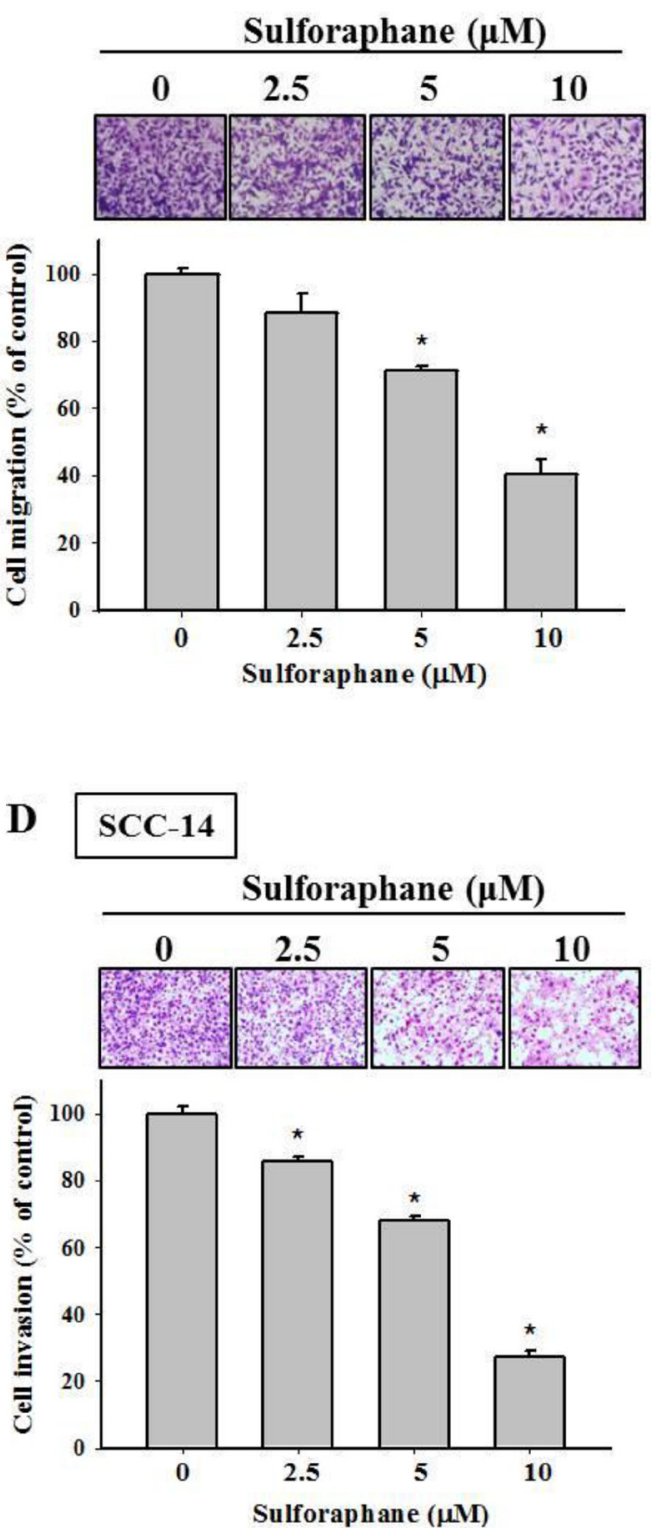

Figure 2: Effect of sulforaphane on cell migration and invasion of SCC-9 and SCC-14 cells. The cell migration (A-B) and invasion (C-D) were measured using a Boyden chamber for $24 \mathrm{~h}$ and $48 \mathrm{~h}$ with polycarbonate filters. The number of cells which invaded the underside of the porous polycarbonate was counted for assessing the migration and invasion abilities of SCC-9 (A, C) and SCC-14 (B, D) cells. The values represented the means $\pm \mathrm{SD}$ of at least 3 independent experiments. ${ }^{*} p<0.05$, compared with the vehicle group. 
A

Sulforaphane $(\mu \mathrm{M})$

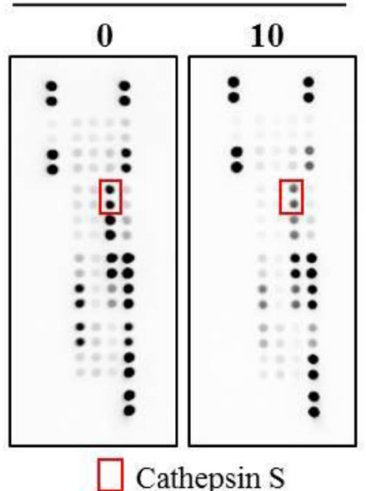

C

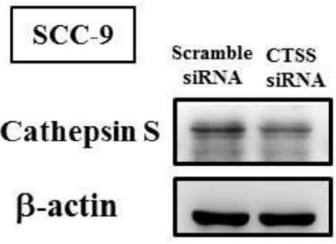

SCC-14

Cathepsin S $=$

$\beta$-actin

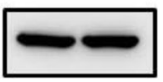

E

SCC-9

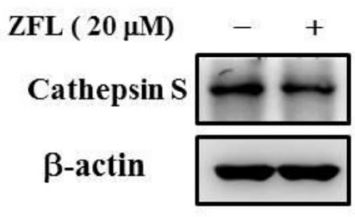

\section{SCC-14}

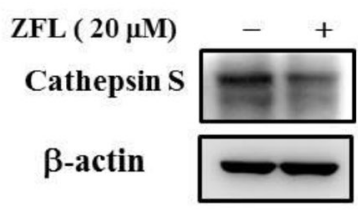

B

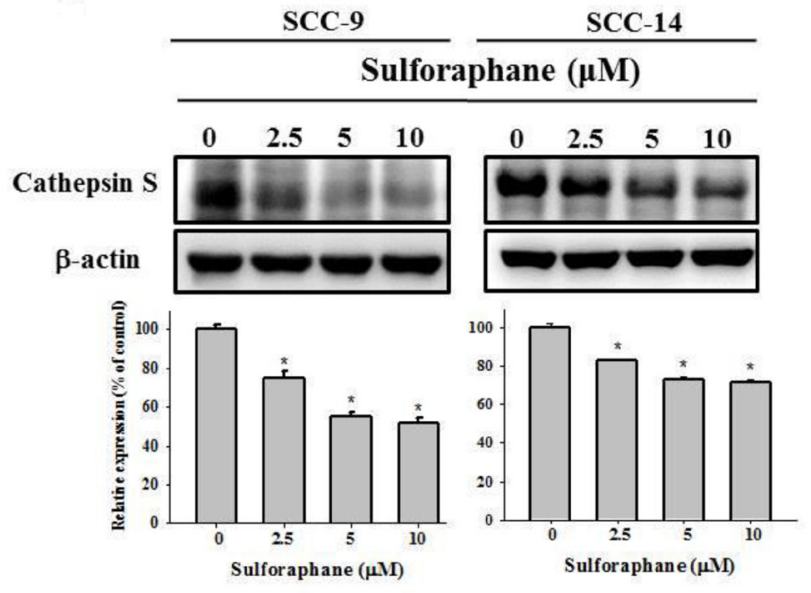

D
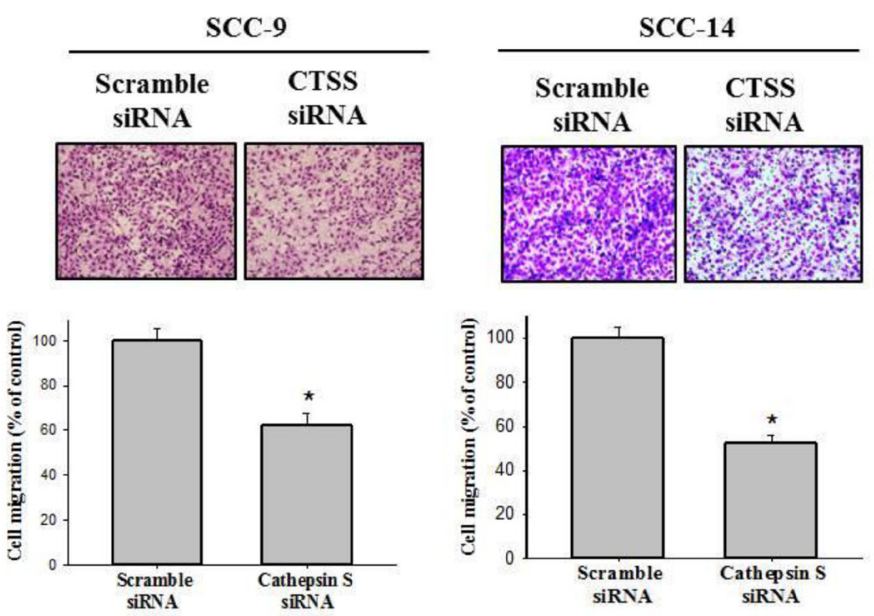

F
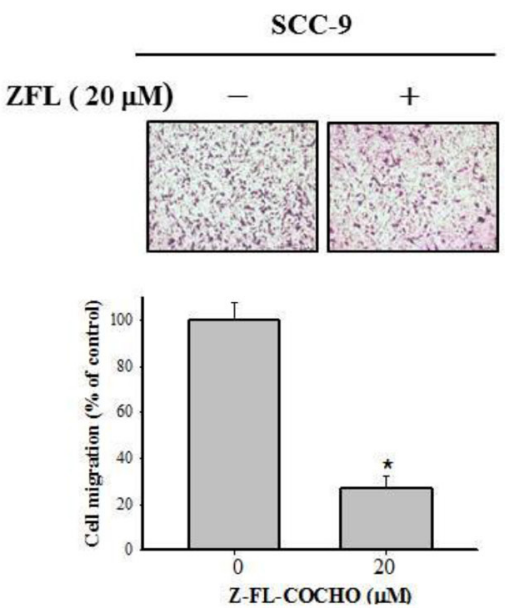

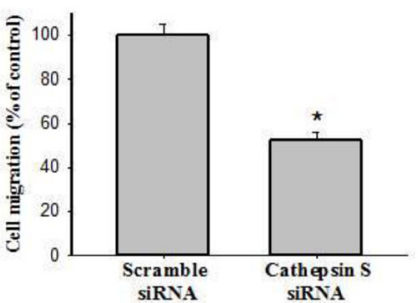

siRNA
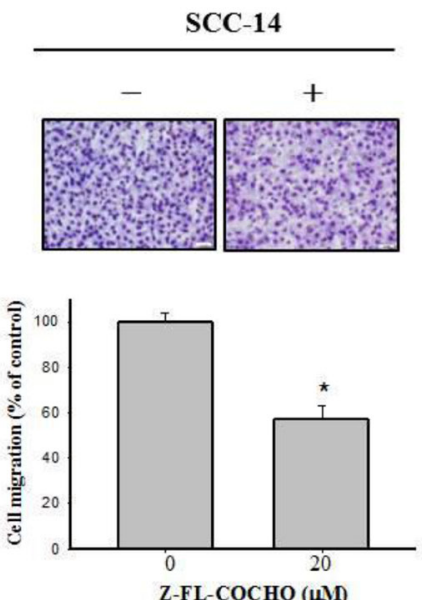

Figure 3: Effect of sulforaphane on the protein expression of cathepsin S of SCC-9 and SCC-14 cells. (A) The cell protein lysate was collected and detected the protein expression by Human Proteinases Array. (B) The expressions of cathepsin S protein on the treatments of SCC-9 and SCC-14 cells were assessed by western blot. The values represented the means \pm SD of at least 3 independent experiments. (C-D) SCC-9 and SCC-14 cells transfected with the siRNA of cathepsin S for $48 \mathrm{~h}$ and analyzed by western blot and Boyden chamber migration assay. (E-F). The cells were treated with cathepsin S inhibitor Z-FL-COCHO $(20 \mu \mathrm{M})$ for $24 \mathrm{~h}$ then analyzed by western blot and Boyden chamber migration assay. The values represented the mean \pm S.D. from 3 determinations per condition repeated 3 times. ${ }^{*} p<0.05$, compared with the vehicle group. 
Cathepsin $\mathrm{S}$ is a member of the cathepsin family that is predominantly expressed in antigen-presenting cells [31]. However, cathepsin $\mathrm{S}$ is also expressed in epithelial cells and various malignant tumor cells. Further insight into the roles of cathepsin $\mathrm{S}$ in tumorigenesis has been provided by the upregulation of cathepsin $\mathrm{S}$ in various tumor tissues $[32,33]$. In addition, studies have indicated the significance of the relationship between cathepsin $\mathrm{S}$ and autophagy [11, 12, 28, 34, 35]. Zhang et al. revealed that the inhibition of cathepsin $\mathrm{S}$ induces autophagy through ROS-mediated PI3K/AKT/mTOR/p70S6K pathways [11]. Targeting cathepsin $\mathrm{S}$ induces autophagy and the conversion of LC3-I into LC3-II [12]. Lipidated LC3 is a useful marker of autophagic membranes. Our data clearly indicated that sulforaphane treatment can suppress the expression of cathepsin $\mathrm{S}$ and upregulate the expression of LC3-II (Figures 3A, 4A, and 4B). In addition, we discovered that knockdown of LC3 increased migration ability compared with that in the control group (Figure 5A and 5B). These results are in agreement with data reported by Zhao et al. [36], which demonstrated that low expression of LC3 contributed to a more aggressive cancer cell phenotype. In this study, targeting cathepsin $\mathrm{S}$ induced the conversion of LC3-I into LC3-II. In line with this finding, Chen et al. indicated that the downregulation of cathepsin $\mathrm{S}$ resulted in an increase of LC3-II and activation of the EGFRrelated ERK/MAPK signaling pathway [12]. Mounting evidence indicates that the regulation of autophagy is complicated and several pathways are involved [37]. The $\mathrm{AKT} / \mathrm{mTOR}$ and beclin 1 pathways have been revealed to be major regulators of the autophagic process [38, 39]. Nevertheless, our data indicated that the phosphorylation of AKT and mTOR, as well as the expression of beclin 1 , is not affected by sulforaphane treatment (Figure 6A). The beclin 1-independent pathway was determined to be a noncanonical autophagy pathway in human breast cancer cells treated with resveratrol [40]. Kang et al. indicated that trehalose-induced autophagy is independent
A $\mathrm{SCC}-9$
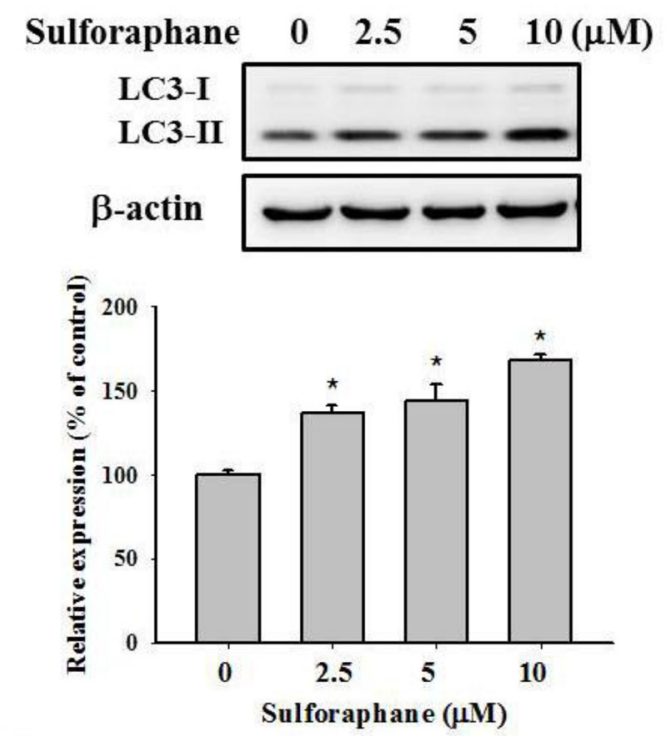

C

Sulforaphane $(\mu \mathrm{M})$

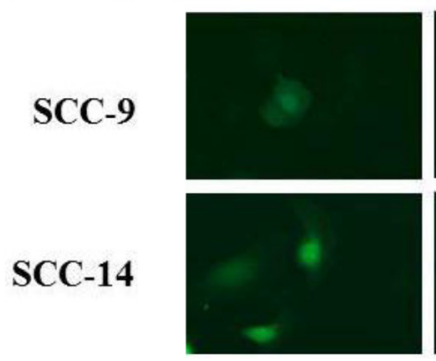

B

\section{SCC-14}

$\begin{array}{lllll}\text { Sulforaphane } & 0 & 2.5 & 5 & 10(\mu \mathrm{M})\end{array}$ LC3-I
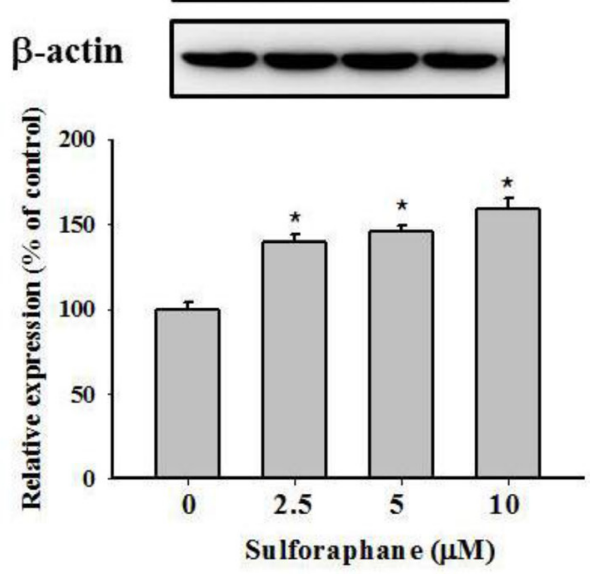

2.5

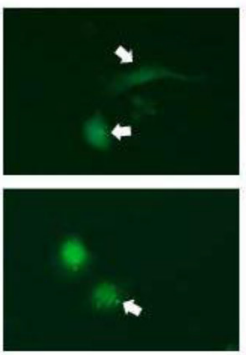

5

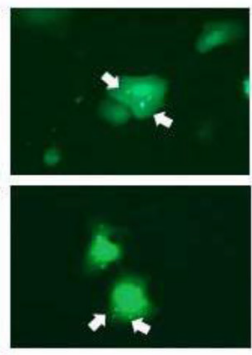

10

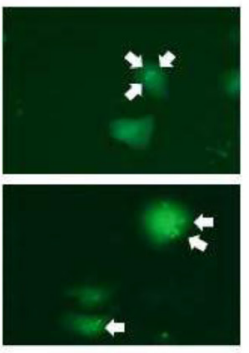

Figure 4: Effect of sulforaphane on the LC3 expression of SCC-9 and SCC-14 cells. The expressions of LC3 protein on the treatments of (A) SCC-9 and (B) SCC-14 cells were assessed by western blot. The values represented the means \pm SD of at least three independent experiments. ${ }^{*} p<0.05$, compared with the vehicle group. (C). GFP-LC3 dots were observed after the cells transfected with the plasmid and sulforaphane treatment. 
of mTOR and ROS in human podocytes [41]. Hence, much research remains to be conducted to discern the precise mechanism underlying sulforaphane treatment. In addition, several pathways are involved in the regulatory mechanism of the inhibition of migration by sulforaphane. Our results indicated that sulforaphane induced ERK1/2 phosphorylation. These data are consistent with those reported in the previous studies; sulforaphane triggered the ERK1/2 signaling pathway by increasing ROS [42, 43]. Moreover, Mondal et al. also stated that sulforaphane inhibits gastric cancer cell migration via EGFR and ERK1/2 pathway [44]. Our previous study demonstrated that hispolon suppresses metastasis through the autophagic degradation of cathepsin $\mathrm{S}$ with the activation of ERK in cervical cancer cells [28]. Additionally, the MEK inhibitor U0126 was used to show that sulforaphane inhibits cell migration through ERK activation (Figure 6C). Furthermore, Wang et al. suggested that sulforaphane inhibits thyroid cancer cell growth and invasiveness by enhancing p21 expression through the activation of ERK signaling cascades [45].

Collectively, our data provide evidence that sulforaphane inhibits human oral cancer cell migration by suppressing cathepsin $\mathrm{S}$ and the downstream target

$\mathbf{A}$
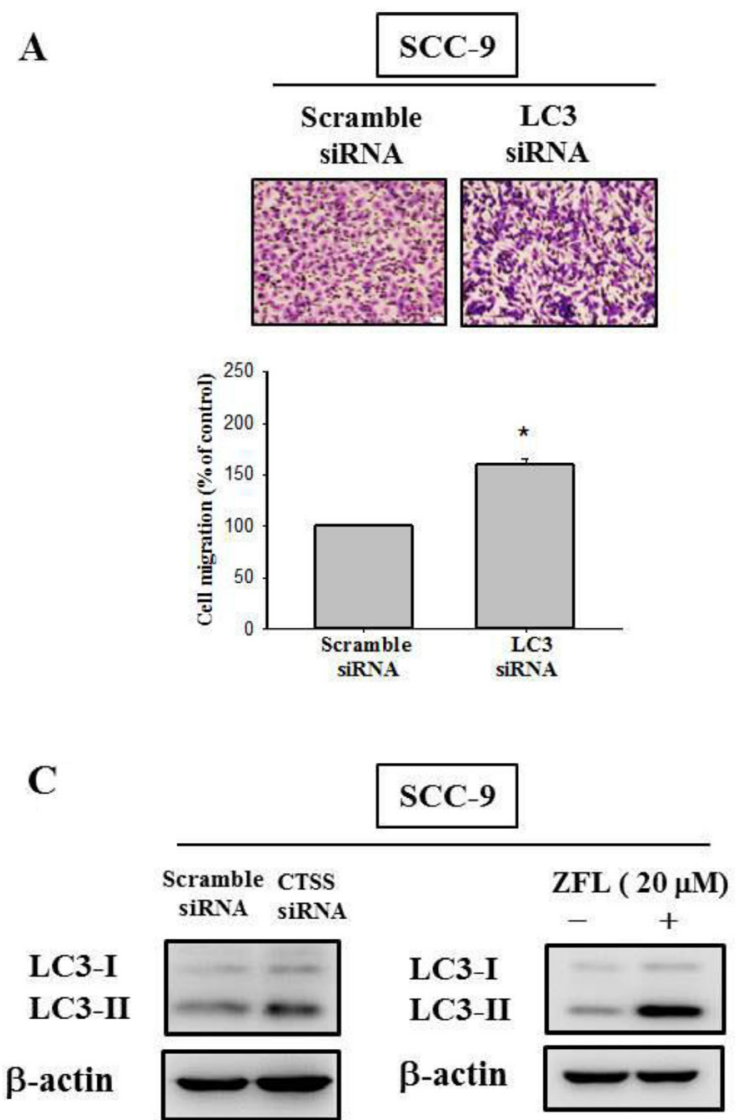

protein LC3. Furthermore, the ERK/MAPK pathways are involved in the regulation of oral cancer cell treatment with sulforaphane. Our findings suggest that cathepsin S and LC3 may be novel targets for oral cancer treatment.

\section{MATERIALS AND METHODS}

\section{Material and chemicals}

Sulforaphane was purchased from Sigma-Aldrich (St. Louis, MO) and the percent purity was over $90 \%$ determined by HPLC. Z-FL-COCHO was purchased from Calbiochem/EMD Millipore (Billerica, MA). MEK inhibitor U0126 was purchased from Promega (Heidelberg, Germany).

\section{Cell lines and culture}

SCC-9 (human tongue squamous cell carcinoma, 25 year old male) obtained from ATCC (Manassas, VA, USA). SCC-14, a human floor of mouth squamous cell carcinoma cell line was purchased from CLS Cell Line Service GmbH (Eppelheim, Germany). Both of the cell lines cultured in DMEM/F-12 medium, $10 \%$ and $5 \%$ fetal

\section{B}
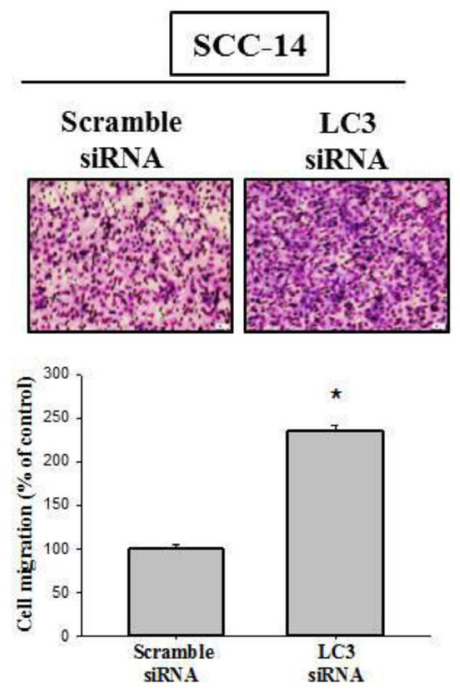

D

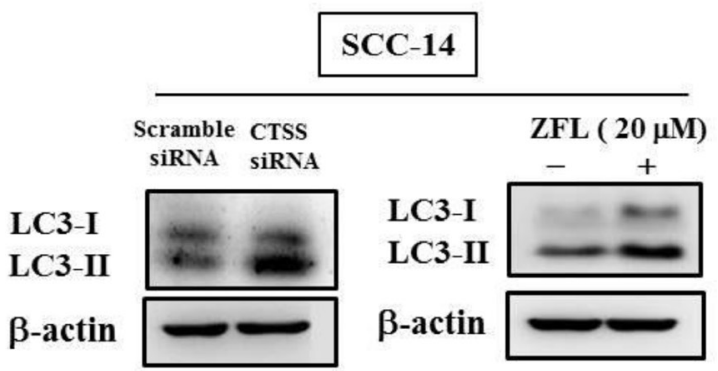

Figure 5: Effect of LC3 siRNA on the cell migration of SCC-9 and SCC-14 cells. (A) SCC-9 and (B) SCC-14 cells transfected with the siRNA of LC3 for $48 \mathrm{~h}$ and analyzed by Boyden chamber migration assay. The values represented the mean \pm S.D. from 3 determinations per condition repeated 3 times. ${ }^{*} p<0.05$, compared with the vehicle group. The (C) SCC-9 and (D) SCC-14 cells were treated with cathepsin S siRNA and cathepsin S inhibitor Z-FL-COCHO $(20 \mu \mathrm{M})$ for $24 \mathrm{~h}$ then analyzed by western blot. 
A Sulforaphane $(\mu \mathrm{M})$ $\begin{array}{llll}0 & 2.5 & 5 & 10\end{array}$

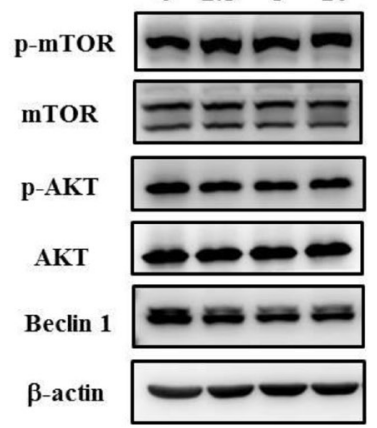

B

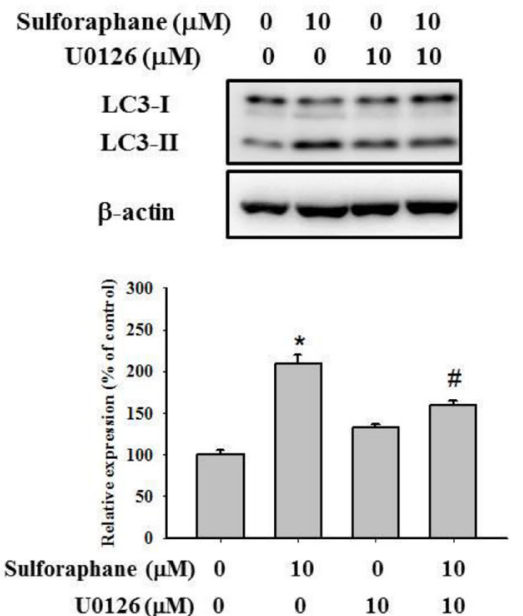

p-JNK 1/2
Sulforaphane $(\mu M)$

$\begin{array}{llll}0 & 2.5 & 5 & 10\end{array}$ p-ERK 1/2 —-

ERK $1 / 2000$

p-p38 $1+1+1+1$

p38

JNK 1/2

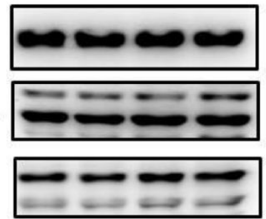

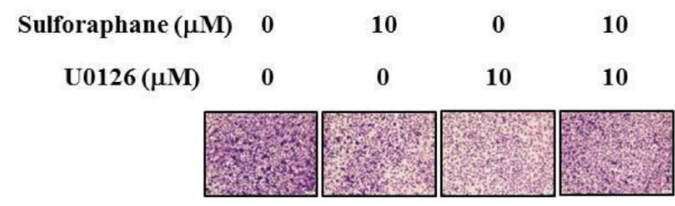

C

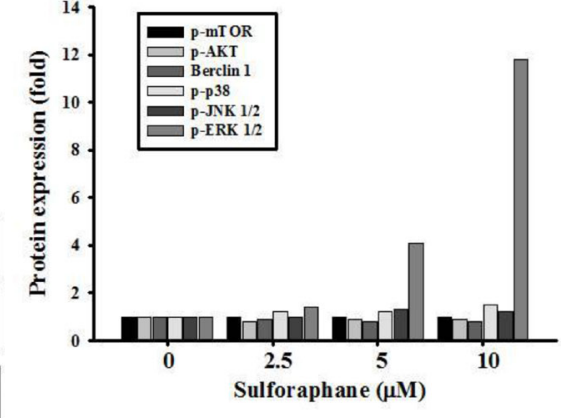

D
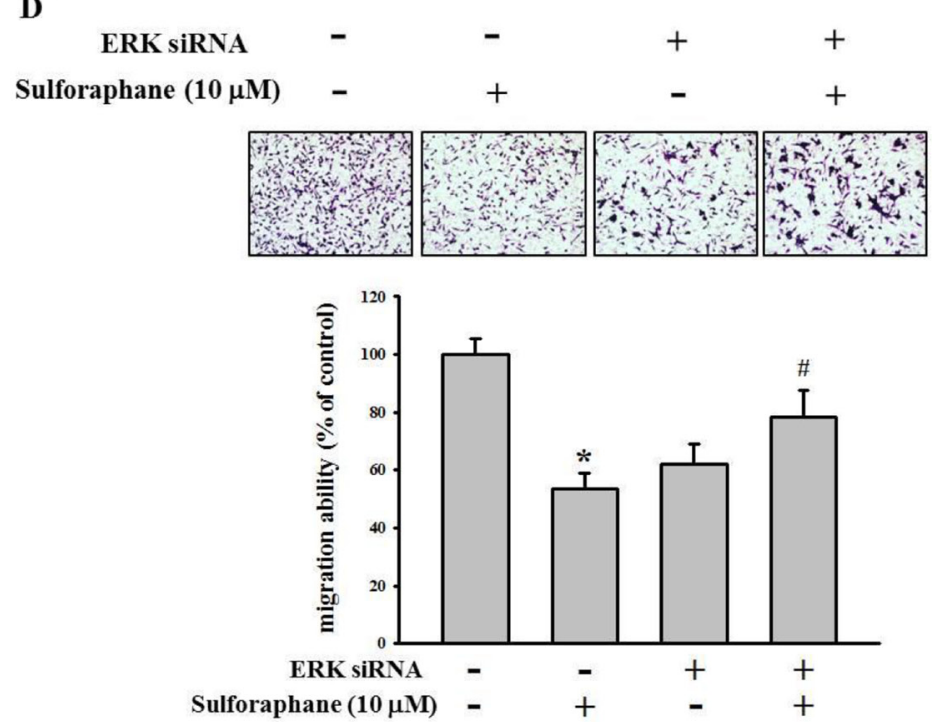

Figure 6: Effect of sulforaphane on the mTOR/AKT and MAPKs pathway. (A). After a $24 \mathrm{~h}$ culture in various concentrations of sulforaphane $(0,2.5,5$ and $10 \mu \mathrm{M})$ for $24 \mathrm{~h}$, the lysates of SCC-9 cells were subjected to SDS-PAGE followed by western blots with anti-mTOR, anti-AKT, anti-Beclin 1, anti-ERK, anti-JNK and anti-p38 (total and phosphorylated) antibodies. (B-C). SCC-9 cells were pretreated with or without $\mathrm{U} 0126(10 \mu \mathrm{M})$ for $1 \mathrm{~h}$ and then incubated in the presence or absence of combined sulforaphane $(10 \mu \mathrm{M})$ for $23 \mathrm{~h}$. The weastern blot assay was used for measurement of LC3 expression. Analysis of (C) cell migration of SCC-9 cells were assessed as described in Methods Section. (D) SCC-9 cells were pretreated with or without ERK siRNA ( 80 pmole) for $24 \mathrm{~h}$ and then incubated in the presence or absence of combined sulforaphane $(10 \mu \mathrm{M})$ for $24 \mathrm{~h}$. The values represented the means \pm SD of at least 3 independent experiments. ${ }^{*} p<0.05$, compared with the vehicle group. ${ }^{*} p<0.05$, compared with the sulforaphane treated group. 
bovine serum, respectively, $2 \mathrm{mM}$ glutamine, $400 \mathrm{ng} / \mathrm{ml}$ hydrocortisone, $100 \mathrm{U} / \mathrm{ml}$ penicillin, and $100 \mu \mathrm{g} / \mathrm{ml}$ streptomycin (Sigma). The cultures were maintained at $37^{\circ} \mathrm{C}$ in a humidified atmosphere of $5 \% \mathrm{CO} 2$.

\section{Cell viability assay}

SCC-9 and SCC-14 cells were plated at a density of $8 \times 10^{4}$ and $1.1 \times 10^{5}$ cells/well in 24-well plates and treated with sulforaphane $(0,2.5,5$ and $10 \mu \mathrm{M})$ at $37^{\circ} \mathrm{C}$ for $24 \mathrm{~h}$ and $48 \mathrm{~h}$, respectively. To determined cell viability, a microculture tetrazolium dye MTT (3-(4,5-dimethylthiazol-2-yl)-2,5-diphenyltetrazolium bromide) assay was performed, as described [46].

\section{Wound healing assay}

SCC-9 and SCC-14 cells were grown onto 6-well plates and incubated overnight. Then the cells were scratched a line with pipette tips then treated with different concentrations of sulforaphane. We detected the ability of cell healing on different times by microscopy and measured the change of the mean number of cells from 3 replicates.

\section{Cell migration and invasion assay}

The migration assay of SCC-9 cells was performed using Boyden chamber (Neuro Probe, Cabin John, MD, USA) for $24 \mathrm{~h}$ as described by Chung et al [47]. SCC14 cells were seeded on Transwell inserts (Millipore, Bedford, MA, USA) at $10^{4}$ cells/well in serum-free medium and placed in the upper chamber then incubated for $48 \mathrm{~h}$. For invasion assay, $10 \mu \mathrm{l}$ Matrigel $(25 \mathrm{mg} / 50 \mathrm{ml}$; BD Biosciences, MA, USA) was applied to polycarbonate membrane filters and the bottom chamber contained standard medium. The cell migratory abilities were determined by counting the migrated cells in five fields under high magnification.

\section{Western blot assay}

SCC-9 and SCC-14 cells were seeded $6 \times 10^{5}$ and $1.2 \times 10^{6}$ onto $6 \mathrm{~cm}$ dish, respectively, and treated with sulforaphane. Cell lysate were collected with $50-100 \mu \mathrm{L}$ of protein extraction solution (iNtRON Biotechnology, Seongnam, Korea) as previously described [48]. After centrifuged at $13000 \mathrm{~g}$ at $4^{\circ} \mathrm{C}$ for $30 \mathrm{~min}$. The protein lysate were separated by $12 \%$ agarose gel and transferred onto a nitrocellulose membrane then blocking with 5\% non-fat milk in Tris-buffered saline (20 mM Tris, $137 \mathrm{mM} \mathrm{NaCl}, \mathrm{pH}$ 7.6) for $1 \mathrm{~h}$ in room temperature and overnight with firstantibodies in $4^{\circ} \mathrm{C}$ and second-antibodies for $1 \mathrm{~h}$ in room temperature. Anti-p-ERK, anti-ERK, anti-JNK, anti-p-JNK, anti-p-Akt, anti-LC3I, anti-Beclin 1, anti-p-mTOR, antimTOR were purchased from Cell Signaling Technology (Danvers, MA, USA). Anti-Akt, anti-pp38, anti-p38 were purchased from BD Biosciences (Bedford, MA, USA).
Anti-cathepsin S was purchased from GeneTex (CA, USA). The band intensities were quantified by densitometry.

\section{GFP-LC3 transfection and GFP-LC3 dot formation}

The cells were culture overnight then transfected with GFP-LC3 as previously described [28]. After incubated for overnight, the cells were treated with sulforaphane $(0-10 \mu \mathrm{M})$ for $24 \mathrm{~h}$. The GFP-LC3 punctated dots in cells were obtained using fluorescence microscope.

\section{Small interfering RNA (siRNA) system}

siRNA oligonucleotide duplexes targeting human cathepsin S and LC3B were purchased from Invitrogen (Carlsbad, CA). SCC-9 and SCC-14 cells were seeded $6 \times 10^{5}$ and $1.2 \times 10^{6}$ onto $6 \mathrm{~cm}$ dish, respectively. After cultured for $24 \mathrm{~h}$, cells were transfected with siRNA for 48 $\mathrm{h}$ using Lipofectamine 2000 (Invitrogen) according to the manufacture's instructions.

\section{Statistical analysis}

The statistical analysis was performed using the Student's $t$-test (SPSS, Chicago, IL, USA). Significance was set at $p<0.05$. The values are the means \pm standard deviation (SD) of at least three independent experiments.

\section{Author contributions}

CTC, MJH, JSY, CWL conceived and designed the experiments; MJH, YHH, MCH, JSY and YTC performed the experiments; CTC and SFY analyzed the data; CTC, $\mathrm{MJH}, \mathrm{SFY}$ and CWL wrote the paper.

\section{CONFLICTS OF INTEREST}

The authors declared no conflicts of interest.

\section{FUNDING}

This study was supported by research grants from the Ministry of Science and Technology, Taiwan (MOST106-2314-B-040 -011-MY3) and from Chung Shan Medical University Hospital, Taiwan (CSH-2017-C-018).

\section{REFERENCES}

1. Santosh AB, Jones T, Harvey J. A review on oral cancer biomarkers: Understanding the past and learning from the present. J Cancer Res Ther. 2016; 12:486-92. https://doi. org/10.4103/0973-1482.176414.

2. Cairns RA, Khokha R, Hill RP. Molecular mechanisms of tumor invasion and metastasis: an integrated view. Curr Mol Med. 2003; 3:659-71. 
3. Su SC, Hsieh MJ, Yang WE, Chung WH, Reiter RJ, Yang SF. Cancer metastasis: Mechanisms of inhibition by melatonin. $\mathrm{J}$ Pineal Res. 2017; 62. https://doi.org/10.1111/jpi.12370.

4. Petanceska S, Canoll P, Devi LA. Expression of rat cathepsin S in phagocytic cells. J Biol Chem. 1996; 271:4403-9.

5. Gocheva V, Zeng W, Ke D, Klimstra D, Reinheckel T, Peters C, Hanahan D, Joyce JA. Distinct roles for cysteine cathepsin genes in multistage tumorigenesis. Genes Dev. 2006; 20:543-56. https://doi.org/10.1101/gad.1407406.

6. Tsai JY, Lee MJ, Dah-Tsyr Chang M, Huang H. The effect of catalase on migration and invasion of lung cancer cells by regulating the activities of cathepsin S, L, and K. Exp Cell Res. 2014; 323:28-40. https://doi.org/10.1016/j. yexcr.2014.02.014.

7. Zhang Z, Zhang H, Peng T, Li D, Xu J. Melittin suppresses cathepsin $\mathrm{S}$-induced invasion and angiogenesis via blocking of the VEGF-A/VEGFR-2/MEK1/ERK1/2 pathway in human hepatocellular carcinoma. Oncol Lett. 2016; 11:610-8. https://doi.org/10.3892/ol.2015.3957.

8. Hsieh MJ, Lin CW, Chen MK, Chien SY, Lo YS, Chuang YC, Hsi YT, Lin CC, Chen JC, Yang SF. Inhibition of cathepsin $\mathrm{S}$ confers sensitivity to methyl protodioscin in oral cancer cells via activation of $\mathrm{p} 38 \mathrm{MAPK} / \mathrm{JNK}$ signaling pathways. Sci Rep. 2017; 7: 45039. https://doi.org/10.1038/ srep45039.

9. Liu WL, Liu D, Cheng K, Liu YJ, Xing S, Chi PD, Liu XH, Xue N, Lai YZ, Guo L, Zhang G. Evaluating the diagnostic and prognostic value of circulating cathepsin $\mathrm{S}$ in gastric cancer. Oncotarget. 2016; 7:28124-38. https://doi. org/10.18632/oncotarget.8582.

10. Tsai JY, Lee MJ, Chang MD, Wang HC, Lin CC, Huang H. Effects of novel human cathepsin $\mathrm{S}$ inhibitors on cell migration in human cancer cells. J Enzyme Inhib Med Chem. 2014; 29:538-46. https://doi.org/10.3109/1475636 6.2013.823957.

11. Zhang L, Wang $\mathrm{H}, \mathrm{Xu} \mathrm{J}$, Zhu J, Ding K. Inhibition of cathepsin $\mathrm{S}$ induces autophagy and apoptosis in human glioblastoma cell lines through ROS-mediated PI3K/ AKT/mTOR/p70S6K and JNK signaling pathways. Toxicol Lett. 2014; 228:248-59. https://doi.org/10.1016/j. toxlet.2014.05.015.

12. Chen KL, Chang WS, Cheung $\mathrm{CH}$, Lin $\mathrm{CC}$, Huang $\mathrm{CC}$, Yang YN, Kuo CP, Kuo CC, Chang YH, Liu KJ, Wu CM, Chang JY. Targeting cathepsin S induces tumor cell autophagy via the EGFR-ERK signaling pathway. Cancer Lett. 2012; 317:89-98. https://doi.org/10.1016/j. canlet.2011.11.015.

13. Mizushima N, Levine B, Cuervo AM, Klionsky DJ. Autophagy fights disease through cellular self-digestion. Nature. 2008; 451:1069-75. https://doi.org/10.1038/ nature06639.

14. Maycotte P, Thorburn A. Targeting autophagy in breast cancer. World J Clin Oncol. 2014; 5:224-40. https://doi. org/10.5306/wjco.v5.i3.224.
15. Cheung KL, Kong AN. Molecular targets of dietary phenethyl isothiocyanate and sulforaphane for cancer chemoprevention. AAPS J. 2010; 12:87-97. https://doi. org/10.1208/s12248-009-9162-8.

16. Tarozzi A, Angeloni C, Malaguti M, Morroni F, Hrelia S, Hrelia P. Sulforaphane as a potential protective phytochemical against neurodegenerative diseases. Oxid Med Cell Longev. 2013; 2013: 415078. https://doi. org/10.1155/2013/415078.

17. Fisher ML, Ciavattone N, Grun D, Adhikary G, Eckert RL. Sulforaphane reduces YAP/Np63alpha signaling to reduce cancer stem cell survival and tumor formation. Oncotarget. 2017; 8:73407-18. https://doi.org/10.18632/ oncotarget.20562.

18. Liu P, Atkinson SJ, Akbareian SE, Zhou Z, Munsterberg A, Robinson SD, Bao Y. Sulforaphane exerts anti-angiogenesis effects against hepatocellular carcinoma through inhibition of STAT3/HIF-1alpha/VEGF signalling. Sci Rep. 2017; 7: 12651. https://doi.org/10.1038/s41598-017-12855-w.

19. Li QQ, Xie YK, Wu Y, Li LL, Liu Y, Miao XB, Liu QZ, Yao KT, Xiao GH. Sulforaphane inhibits cancer stem-like cell properties and cisplatin resistance through miR-214mediated downregulation of c-MYC in non-small cell lung cancer. Oncotarget. 2017; 8:12067-80. https://doi. org/10.18632/oncotarget.14512.

20. Liu CM, Peng CY, Liao YW, Lu MY, Tsai ML, Yeh JC, $\mathrm{Yu} \mathrm{CH}$, Yu CC. Sulforaphane targets cancer stemness and tumor initiating properties in oral squamous cell carcinomas via miR-200c induction. J Formos Med Assoc. 2017; 116:41-8. https://doi.org/10.1016/j.jfma.2016.01.004.

21. Wu S, Zhou Y, Yang G, Tian H, Geng Y, Hu Y, Lin K, $\mathrm{Wu}$ W. Sulforaphane-cysteine induces apoptosis by sustained activation of ERK1/2 and caspase 3 in human glioblastoma U373MG and U87MG cells. Oncol Rep. 2017; 37:2829-38. https://doi.org/10.3892/or.2017.5562.

22. Bertl E, Bartsch H, Gerhauser C. Inhibition of angiogenesis and endothelial cell functions are novel sulforaphanemediated mechanisms in chemoprevention. Mol Cancer Ther. 2006; 5:575-85. https://doi.org/10.1158/1535-7163. met-05-0324.

23. Paolini M, Perocco P, Canistro D, Valgimigli L, Pedulli GF, Iori R, Croce CD, Cantelli-Forti G, Legator MS, AbdelRahman SZ. Induction of cytochrome P450, generation of oxidative stress and in vitro cell-transforming and DNAdamaging activities by glucoraphanin, the bioprecursor of the chemopreventive agent sulforaphane found in broccoli. Carcinogenesis. 2004; 25:61-7. https://doi.org/10.1093/ carcin/bgg 174 .

24. Myzak MC, Dashwood WM, Orner GA, Ho E, Dashwood RH. Sulforaphane inhibits histone deacetylase in vivo and suppresses tumorigenesis in Apc-minus mice. FASEB J. 2006; 20:506-8. https://doi.org/10.1096/ fj.05-4785fje.

25. Cho SD, Li G, Hu H, Jiang C, Kang KS, Lee YS, Kim SH, $\mathrm{Lu}$ J. Involvement of c-Jun N-terminal kinase in G2/M arrest 
and caspase-mediated apoptosis induced by sulforaphane in DU145 prostate cancer cells. Nutr Cancer. 2005; 52:21324. https://doi.org/10.1207/s15327914nc5202_11.

26. Singh SV, Srivastava SK, Choi S, Lew KL, Antosiewicz J, Xiao D, Zeng Y, Watkins SC, Johnson CS, Trump DL, Lee YJ, Xiao H, Herman-Antosiewicz A. Sulforaphaneinduced cell death in human prostate cancer cells is initiated by reactive oxygen species. J Biol Chem. 2005; 280:1991124. https://doi.org/10.1074/jbc.M412443200.

27. Fahey JW, Haristoy X, Dolan PM, Kensler TW, Scholtus I, Stephenson KK, Talalay P, Lozniewski A. Sulforaphane inhibits extracellular, intracellular, and antibiotic-resistant strains of Helicobacter pylori and prevents benzo[a]pyreneinduced stomach tumors. Proc Natl Acad Sci U S A. 2002; 99:7610-5. https://doi.org/10.1073/pnas.112203099.

28. Hsin MC, Hsieh YH, Wang PH, Ko JL, Hsin IL, Yang SF. Hispolon suppresses metastasis via autophagic degradation of cathepsin S in cervical cancer cells. Cell Death Dis. 2017; 8: e3089. https://doi.org/10.1038/cddis.2017.459.

29. Kotecha R, Takami A, Espinoza JL. Dietary phytochemicals and cancer chemoprevention: a review of the clinical evidence. Oncotarget. 2016; 7:52517-29. https://doi. org/10.18632/oncotarget.9593.

30. Boddupalli S, Mein JR, Lakkanna S, James DR. Induction of phase 2 antioxidant enzymes by broccoli sulforaphane: perspectives in maintaining the antioxidant activity of vitamins a, C, and e. Front Genet. 2012; 3:7. https://doi. org/10.3389/fgene.2012.00007.

31. Kos J, Sekirnik A, Kopitar G, Cimerman N, Kayser K, Stremmer A, Fiehn W, Werle B. Cathepsin S in tumours, regional lymph nodes and sera of patients with lung cancer: relation to prognosis. Br J Cancer. 2001; 85:1193-200. https://doi.org/10.1054/bjoc.2001.2057.

32. Wilkinson RD, Williams R, Scott CJ, Burden RE. Cathepsin S: therapeutic, diagnostic, and prognostic potential. Biol Chem. 2015; 396:867-82. https://doi. org/10.1515/hsz-2015-0114.

33. Zhang L, Wang $\mathrm{H}, \mathrm{Xu}$ J. Cathepsin $\mathrm{S}$ as a cancer target. Neoplasma. 2015; 62:16-26.

34. Huang CC, Chen KL, Cheung CH, Chang JY. Autophagy induced by cathepsin $\mathrm{S}$ inhibition induces early ROS production, oxidative DNA damage, and cell death via xanthine oxidase. Free Radic Biol Med. 2013; 65:1473-86. https://doi.org/10.1016/j.freeradbiomed.2013.07.020.

35. Yang M, Liu J, Shao J, Qin Y, Ji Q, Zhang X, Du J. Cathepsin S-mediated autophagic flux in tumor-associated macrophages accelerate tumor development by promoting M2 polarization. Mol Cancer. 2014; 13: 43. https://doi. org/10.1186/1476-4598-13-43.

36. Zhao H, Yang M, Zhao B. Beclin 1 and LC3 as predictive biomarkers for metastatic colorectal carcinoma. Oncotarget. 2017; 8:59058-67. https://doi.org/10.18632/ oncotarget.19939.

37. Nagelkerke A, Sweep FC, Geurts-Moespot A, Bussink J, Span PN. Therapeutic targeting of autophagy in cancer.
Part I: molecular pathways controlling autophagy. Semin Cancer Biol. 2015; 31:89-98. https://doi.org/10.1016/j. semcancer.2014.05.004.

38. Liang XH, Jackson S, Seaman M, Brown K, Kempkes B, Hibshoosh H, Levine B. Induction of autophagy and inhibition of tumorigenesis by beclin 1. Nature. 1999; 402:672-6. https://doi.org/10.1038/45257.

39. Roy B, Pattanaik AK, Das J, Bhutia SK, Behera B, Singh P, Maiti TK. Role of PI3K/Akt/mTOR and MEK/ERK pathway in Concanavalin A induced autophagy in HeLa cells. Chem Biol Interact. 2014; 210:96-102. https://doi. org/10.1016/j.cbi.2014.01.003.

40. Scarlatti F, Maffei R, Beau I, Codogno P, Ghidoni R. Role of non-canonical Beclin 1-independent autophagy in cell death induced by resveratrol in human breast cancer cells. Cell Death Differ. 2008; 15:1318-29. https://doi. org/10.1038/cdd.2008.51.

41. Kang YL, Saleem MA, Chan KW, Yung BY, Law HK. Trehalose, an mTOR independent autophagy inducer, alleviates human podocyte injury after puromycin aminonucleoside treatment. PLoS One. 2014; 9: e113520. https://doi.org/10.1371/journal.pone.0113520.

42. Li C, Zhou Y, Peng X, Du L, Tian H, Yang G, Niu J, Wu W. Sulforaphane inhibits invasion via activating ERK1/2 signaling in human glioblastoma U87MG and U373MG cells. PLoS One. 2014; 9: e90520. https://doi.org/10.1371/ journal.pone.0090520.

43. Peng X, Zhou Y, Tian H, Yang G, Li C, Geng Y, Wu S, $\mathrm{Wu} \mathrm{W}$. Sulforaphane inhibits invasion by phosphorylating ERK1/2 to regulate E-cadherin and CD44v6 in human prostate cancer DU145 cells. Oncol Rep. 2015; 34:1565-72. https://doi.org/10.3892/or.2015.4098.

44. Mondal A, Biswas R, Rhee YH, Kim J, Ahn JC. Sulforaphene promotes $\mathrm{Bax} / \mathrm{Bcl} 2$, MAPK-dependent human gastric cancer AGS cells apoptosis and inhibits migration via EGFR, p-ERK1/2 down-regulation. Gen Physiol Biophys. 2016; 35:25-34. https://doi.org/10.4149/ gpb_2015033.

45. Wang L, Tian Z, Yang Q, Li H, Guan H, Shi B, Hou P, Ji M. Sulforaphane inhibits thyroid cancer cell growth and invasiveness through the reactive oxygen speciesdependent pathway. Oncotarget. 2015; 6:25917-31. https:// doi.org/10.18632/oncotarget.4542.

46. Yang JS, Lin CW, Hsin CH, Hsieh MJ, Chang YC. Selaginellatamariscina attenuates metastasis via Akt pathways in oral cancer cells. PLoS One. 2013; 8: e68035. https://doi.org/10.1371/journal.pone.0068035.

47. Chung TT, Chuang CY, Teng YH, Hsieh MJ, Lai JC, Chuang YT, Chen MK, Yang SF. Tricetin suppresses human oral cancer cell migration by reducing matrix metalloproteinase-9 expression through the mitogenactivated protein kinase signaling pathway. Environ Toxicol. 2017; 32:2392-9. https://doi.org/10.1002/tox.22452. 
48. Ho HY, Lin CW, Chien MH, Reiter RJ, Su SC, Hsieh YH, Yang SF. Melatonin suppresses TPA-induced metastasis by downregulating matrix metalloproteinase- 9 expression through
JNK/SP-1 signaling in nasopharyngeal carcinoma. J Pineal Res. 2016; 61:479-92. https://doi.org/10.1111/jpi.12365. 